\title{
Metastatic Human Papillomavirus-Related Malignant Neoplasm
}

National Cancer Institute

\section{Source}

National Cancer Institute. Metastatic Human Papillomavirus-Related Malignant

Neoplasm. NCI Thesaurus. Code C156793.

A malignant neoplasm that is associated with human papillomavirus infection and has spread from its original site of growth to another anatomic site. 